\title{
Associative Long-Term Depression in the Hippocampus Is Dependent on Postsynaptic N-Type $\mathrm{Ca}^{2+}$ Channels
}

\author{
Claus Normann, ${ }^{1,2}$ Diana Peckys, ${ }^{1}$ Christian H. Schulze, ${ }^{1}$ Jörg Walden, ${ }^{2}$ Peter Jonas, ${ }^{1}$ and \\ Josef Bischofberger ${ }^{1}$
}

1/nstitute of Physiology, University of Freiburg, D-79104 Freiburg, Germany, and 2Department of Psychiatry, University of
Freiburg, D-79104 Freiburg, Germany

\begin{abstract}
Long-term depression (LTD) is a form of synaptic plasticity that can be induced either by low-frequency stimulation of presynaptic fibers or in an associative manner by asynchronous pairing of presynaptic and postsynaptic activity. We investigated the induction mechanisms of associative LTD in CA1 pyramidal neurons of the hippocampus using whole-cell patch-clamp recordings and $\mathrm{Ca}^{2+}$ imaging in acute brain slices. Asynchronous pairing of postsynaptic action potentials with EPSPs evoked with a delay of $20 \mathrm{msec}$ induced a robust, long-lasting depression of the EPSP amplitude to $43 \%$. Unlike LTD induced by lowfrequency stimulation, associative LTD was resistant to the application of D-AP-5, indicating that it is independent of NMDA receptors. In contrast, associative LTD was inhibited by (S)- $\alpha$ methyl-4-carboxyphenyl-glycine, indicating the involvement of metabotropic glutamate receptors. Furthermore, associative LTD is dependent on the activation of voltage-gated $\mathrm{Ca}^{2+}$ channels
\end{abstract}

by postsynaptic action potentials. Both nifedipine, an L-type $\mathrm{Ca}^{2+}$ channel antagonist, and $\omega$-conotoxin GVIA, a selective $\mathrm{N}$-type channel blocker, abolished the induction of associative LTD. 8-hydroxy-2-dipropylaminotetralin (OH-DPAT), a 5- $\mathrm{HT}_{1 \mathrm{~A}}$ receptor agonist, inhibited postsynaptic $\mathrm{Ca}^{2+}$ influx through $\mathrm{N}$-type $\mathrm{Ca}^{2+}$ channels, without affecting presynaptic transmitter release. OH-DPAT also inhibited the induction of associative LTD, suggesting that the involvement of $\mathrm{N}$-type channels makes synaptic plasticity accessible to modulation by neurotransmitters. Thus, the modulation of $\mathrm{N}$-type $\mathrm{Ca}^{2+}$ channels provides a gain control for synaptic depression in hippocampal pyramidal neurons.

Key words: associative long-term depression; hippocampus; $\mathrm{N}$-type $\mathrm{Ca}^{2+}$ channels; NMDA receptors; metabotropic glutamate receptors; asynchronous pairing
Long-term changes in synaptic strength at glutamatergic synapses are thought to underlie complex functions of neuronal networks, such as learning and memory (Bliss and Collingridge, 1993). The frequency of synaptic stimulation determines both the extent and the direction of the change in synaptic efficacy; high-frequency stimulation (HFS) leads to long-term potentiation (LTP), whereas low-frequency stimulation (LFS) results in long-term depression (LTD) (Dudek and Bear, 1992). Whereas several molecular steps of the induction and expression of LTP have been identified, the mechanisms that lead to LTD are less clear.

In the hippocampus, LFS induces two distinct forms of LTD, which depend either on the $\mathrm{Ca}^{2+}$ influx through NMDA receptors (NMDARs) (Mulkey and Malenka, 1992) or on the activation of metabotropic glutamate receptors (mGluRs) (Bolshakov and Siegelbaum, 1994; Oliet et al., 1997; Otani and Connor, 1998). The mGluR LTD appears to be the predominant form in young animals (postnatal days 3-8; Bolshakov and Siegelbaum, 1994), whereas NMDAR LTD and mGluR LTD coexist in older animals (Heynen et al., 1996; Oliet et al., 1997; Otani and Connor, 1998).

Although LFS induces robust changes in synaptic strength, the situation that leads to the induction of hippocampal LTD in vivo could be more complex. CA3 and CA1 pyramidal neurons generate action potentials in a precise temporal relationship, depending on the behavioral context (O'Keefe and Reece, 1993), i.e., pyramidal cells in the center of their place field fire action potentials more early in the theta cycle than neurons with adjacent place fields (Skaggs et al., 1996). Thus, the natural paradigm for LTP and LTD

\footnotetext{
Received May 15, 2000; revised Aug. 14, 2000; accepted Aug. 31, 2000.

This work was supported by a grant from the Deutsche Forschungsgemeinschaft $\mathrm{Bi}$ 642/1-2 and University funds (J.B.) and by the Vada and Theodore Stanley Foundation (J.W.). We thank Drs. M. Bartos, J. R. P. Geiger, and M. Martina for critically reading this manuscript and $\mathrm{A}$. Blomenkamp for technical assistance.

Correspondence should be addressed to Dr. J. Bischofberger, Physiologisches Institut, Universität Freiburg, Hermann-Herder-Strasse 7, D-79104 Freiburg, Germany. E-mail: bischof@uni-freiburg.de.

Copyright (C) 2000 Society for Neuroscience $0270-6474 / 00 / 208290-08 \$ 15.00 / 0$
}

induction is likely to be associative, requiring the temporal coincidence of synaptic activation and backpropagating action potentials (for review, see Linden, 1999). Indeed associative LTD in the hippocampus can be induced by asynchronous pairing of presynaptic and postsynaptic activity (Levy and Steward, 1983; Stanton and Sejnowski, 1989; Stanton et al., 1991). However, the induction mechanisms of associative LTD have remained controversial. Associative LTD in acute slices was reported to be independent of NMDARs (Stanton and Sejnowski, 1989). The opposite was shown for associative LTD in organotypic cell culture (Debanne et al., 1994). Finally, in dissociated hippocampal cell culture, the associative LTD appeared to be dependent on both $\mathrm{Ca}^{2+}$ influx through NMDARs and L-type $\mathrm{Ca}^{2+}$ channels (Bi and Poo, 1998).

Here we investigated the conditions necessary for the induction of associative LTD in acute hippocampal slices by asynchronous paring of presynaptic and postsynaptic activity at the Schaffer collateral-CA1 pyramidal cell synapse. The results suggest that associative LTD is dependent on both mGluRs and $\mathrm{Ca}^{2+}$ influx through voltage-gated $\mathrm{L}$ - and $\mathrm{N}$-type $\mathrm{Ca}^{2+}$ channels. As N-type $\mathrm{Ca}^{2+}$ channels are preferential targets of G-protein-mediated neuromodulation (Hille, 1994), we have tested whether the modulation of postsynaptic $\mathrm{N}$-type $\mathrm{Ca}^{2+}$ channels could affect LTD induction, which would provide a novel mechanism to regulate activitydependent synaptic plasticity in the hippocampus.

\section{MATERIALS AND METHODS}

Slice preparation. Transverse $300-\mu \mathrm{m}$-thick slices were cut from the hippocampus of 11- to 22-d-old Wistar rats with a vibratome (DTK-1000; Dosaka, Kyoto, Japan). For most experiments 14- to 18-d-old animals were used. The animals were killed by decapitation, in accordance with national and institutional guidelines. Slices were kept at $35^{\circ} \mathrm{C}$ for $30 \mathrm{~min}$ after slicing and then at room temperature in physiological extracellular saline containing (in mM): $125 \mathrm{NaCl}, 25 \mathrm{NaHCO}_{3}, 25$ glucose, $2.5 \mathrm{KCl}, 1.25$ $\mathrm{NaH}_{2} \mathrm{PO}_{4}, 2 \mathrm{CaCl}_{2}$, and $1 \mathrm{MgCl}_{2}$, bubbled with carbogene $\left(95 \% \mathrm{O}_{2}\right.$ and $5 \% \mathrm{CO}_{2}$ ).

Electrophysiology. The slices were transferred to the recording chamber and continuously superfused with saline at a flow rate of $5-10 \mathrm{ml} / \mathrm{min}$ (chamber volume, $\sim 2 \mathrm{ml}$ ). CA1 pyramidal neurons were identified by their 
location using infrared differential interference contrast video microscopy and their characteristic firing frequency adaptation during long depolarizing current pulses. Patch pipettes were pulled from borosilicate glass tubing $(2.0 \mathrm{~mm}$ outer diameter, $0.5 \mathrm{~mm}$ wall thickness; Hilgenberg, Malsfeld, Germany) and heat-polished immediately before use. An Axopatch 200A amplifier (Axon Instruments, Foster City, CA) or an EPC-9 amplifier (Heka, Lambrecht, Germany) were used for current-clamp (I-clamp fast) and voltage-clamp recordings. The Axopatch amplifier included a bridge-balance circuit for compensation of series resistance in the currentclamp mode, similar to that of the Axopatch 200B. Current and voltage signals were filtered at 5 and $10 \mathrm{kHz}$, respectively, with a 4-pole lowpass Bessel filter and digitized at 10 or $20 \mathrm{kHz}$ with a 1401plus interface (CED Cambridge, UK). For data acquisition and analysis we used self-made and commercial programs (EPC, CED; Pulse, Heka).

For current-clamp recordings the patch pipettes were filled with an internal solution containing (in $\mathrm{mM}$ ): $135 \mathrm{~K}$-gluconate, $20 \mathrm{KCl}, 2 \mathrm{MgCl}_{2}, 2$ $\mathrm{Na}_{2} \mathrm{ATP}, 0.3 \mathrm{NaGTP}, 0.2-0.5$ EGTA, and 10 HEPES ( $\mathrm{pH}$ was adjusted to 7.3 with $\mathrm{KOH}$ ). Dendritic recordings were performed as described previously (Bischofberger and Jonas, 1997). Patch pipette resistance was 5-10 $\mathrm{M} \Omega$ for somatic and $10-12 \mathrm{M} \Omega$ for dendritic recordings. Bridge balance was used to compensate the series resistance of 20-60 M $\Omega$.

Presynaptic Schaffer collateral fibers were stimulated using a stimulus isolator (List, Darmstadt, Germany) and a patch pipette with a resistance of 1-3 M $\Omega$ when filled with HEPES-buffered $\mathrm{Na}^{+}$-rich solution. The stimulus pipette was placed in the stratum radiatum of the CA1 region $20-50 \mu \mathrm{m}$ away from the pyramidal cell layer. Two hundred microsecond voltage pulses of $10-80 \mathrm{~V}$ were applied to evoke subthreshold EPSPs at a frequency of $0.1 \mathrm{~Hz}$. Orthodromic stimulation was performed in $>90 \%$ of the experiments, and antidromic stimulation was performed in $<10 \%$, without obvious differences concerning basal transmission and plasticity induction. The latency between the center of the stimulus artifact and the onset of the EPSP was $2.9 \pm 0.1 \mathrm{msec}(n=53)$, indicating monosynaptic transmission. Picrotoxin $(20-50 \mu \mathrm{M})$ was present in the external solution of all current-clamp experiments. In some experiments $10 \mu \mathrm{M}$ glycine was added to the bath solution, with no obvious differences in the results.

To record $\mathrm{Ba}^{2+}$ currents, the recording pipettes (mostly $0.8-2 \mathrm{M} \Omega$ ) were filled with a solution containing (in mM): $140 \mathrm{CsCl}, 2 \mathrm{MgCl}_{2}, 2 \mathrm{Na}_{2} \mathrm{ATP}$, $0.3 \mathrm{NaGTP}, 10$ EGTA, and 10 HEPES (pH adjusted to 7.3 with $\mathrm{CsOH}$ ). The bath solution contained $140 \mathrm{NaCl}, 2$ tetraethylammonium chloride (TEACl), $2 \mathrm{MgCl}_{2}, 2 \mathrm{BaCl}_{2}, 1 \mu \mathrm{M}$ tetrodotoxin (TTX) and $10 \mathrm{HEPES}(\mathrm{pH}$ adjusted to 7.4 with $\mathrm{NaOH}$ ). Recordings were made in the voltage-clamp configuration with series resistance $\left(R_{\mathrm{s}}\right)$ compensation (nominally $80-$ 90\%, lag 20-100 $\mu \mathrm{sec} ; R_{\mathrm{s}}$ before compensation 3-10 $\mathrm{M} \Omega$ ). Leak and capacitive currents were subtracted using a $\mathrm{P} /-4$ protocol. For whole-cell voltage-clamp experiments we used only slices from 11- to 13-d-old animals. Thus the CA1 pyramidal cells had relatively short and thin dendrites, minimizing space-clamp artifacts. Voltage-clamp and current-clamp recordings were made at $22-24^{\circ} \mathrm{C}$.

Data analysis and statistics. All values are given as mean \pm SEM, error bars in the figures also represent SEM. The decay time course of EPSPs was fit with a single exponential. To calculate the mean EPSP peak amplitude, 10-15 consecutive EPSPs were averaged from each experiment shortly before and 15-20 min after the end of the induction protocol. The changes in the mean EPSP amplitude were analyzed for each experiment, and statistical significance was assessed by a two-tailed Wilcoxon test at the significance level $(P)$ indicated. Traces shown in the figures represent averages of $10-15$ consecutive sweeps. Average EPSP amplitudes in amplitude-time plots represent means from seven consecutive EPSPs.

Fluorescence measurements. For the measurement of the intracellular $\mathrm{Ca}^{2+}$ signals we used $0.1 \mathrm{~mm}$ fura-2 (Molecular Probes, Eugene, OR) instead of EGTA in the pipette solution. Cells were loaded for at least 15-20 $\mathrm{min}$ in the whole-cell configuration before measurements were started. The excitation light source (Polychrome II with 75 W Xenon lamp; TILL Photonics, Munich, Germany) was coupled to the epifluorescent port of the microscope (Axioskop FS2, Zeiss; 60× water immersion objective, Olympus Optical, Tokyo, Japan) via a light guide. To minimize bleaching, the light intensity was reduced to $10 \%$. The filter combination for excitation and emission comprised a beam splitter (BSP410) and emission filters (LWP420, KP600) from Delta Light \& Optics (Lyngby, Denmark). Some experiments were done with $0.1 \mathrm{~mm}$ Oregon Green (Oregon Green 488 Bapta-1, Molecular Probes) instead of fura-2, using a filter combination from Zeiss (FT510, LP 520) and an excitation light intensity of 5\%.

The fluorescence was measured with a backilluminated frame-transfer CCD camera (EBFT 512; Princeton Instruments). Images with full spatial resolution were taken with exposure times of $5 \mathrm{sec}$. For high-speed $\mathrm{Ca}^{2+}$ measurements $(100 \mathrm{~Hz}$ repetition rate) we usually defined three rectangular regions of interest (ROIs) of $5 \times 5 \mu \mathrm{m}$ at the soma and $5 \times 20 \mu \mathrm{m}$ at a proximal and distal part of the apical dendrite. The pixels included in the ROIs were binned on-chip and digitized subsequently by the controller (Micromax; $1 \mathrm{MHz}$; Princeton Instruments). The fluorescence signals were corrected for background, which was obtained from ROIs shifted by $10-15 \mu \mathrm{m}$ with respect to the original ROIs (Schiller et al., 1995).

Calibration of the $\mathrm{Ca}^{2+}$ measurements with fura-2. To convert the fluorescence signals into $\mathrm{Ca}^{2+}$ concentrations, we used the isosbestic ratioing method (Neher and Augustine, 1992; Schiller et al., 1995). The action potential-induced fluorescence change was recorded at an excitation wavelength of $380 \mathrm{~nm}$. The isosbestic fluorescence was measured immediately before and after this sweep, using an excitation wavelength of $356 \mathrm{~nm}$ (the $\mathrm{Ca}^{2+}$-insensitive wavelength in our experimental conditions). The ratio of the background-corrected fluorescence signals $R=F_{356} / F_{380}$ was calculated and converted into the $\mathrm{Ca}^{2+}$ concentration using the equation (Grynkiewicz et al., 1985):

$$
\left[\mathrm{Ca}^{2+}\right]=K_{\text {eff }}\left(R-R_{\min }\right) /\left(R_{\max }-R\right),
$$

where $R_{\min }$ is the ratio in $\mathrm{Ca}^{2+}$-free solution and $R_{\max }$ the ratio when fura-2 is completely saturated with $\mathrm{Ca}^{2+}$. These values were determined by recording from CA1 pyramidal cells with internal solutions containing either $30 \mathrm{~mm}$ EGTA $\left(R_{\min }=0.70 \pm 0.01 ; n=5\right)$ or $50 \mathrm{mM} \mathrm{CaCl}_{2}\left(R_{\max }=\right.$ $6.97 \pm 0.06 ; n=5) . K_{\text {eff }}$ was calculated according to Neher and Augustine $(1992)$ as $K_{\text {eff }}=K_{\mathrm{d}}\left(R_{\mathrm{max}} / R_{\min }\right)$, with the dissociation constant $K_{\mathrm{d}}=250 \mathrm{nM}$ (Schiller et al., 1995). The resting $\mathrm{Ca}^{2+}$ concentration was on average $47 \pm$ $4 \mathrm{nM}(n=17)$ and $46 \pm 5 \mathrm{nM}(n=17)$ at the soma and dendrite, respectively. The decay time course of the action potential-induced $\mathrm{Ca}^{2+}$ transients was fitted with the sum of two exponentials and the amplitudeweighted $\tau$ was given. Traces in the figures represent averages of 5-10 consecutive sweeps with the fitted curve superimposed.

$\mathrm{Ca}^{2+}$ measurements with Oregon Green. To examine the effects of nifedipine on $\mathrm{Ca}^{2+}$ transients, which is a highly light-sensitive substance, we used $0.1 \mathrm{~mm}$ Oregon Green instead of fura-2. This dye has two advantages: it can be excited with lower energy light in the visible wavelength range (at $480 \mathrm{~nm}$ ) and has a higher quantum yield than fura-2. Thus, we could use a lower excitation intensity $(5 \%)$. In these experiments the relative change in fluorescence intensity $\Delta F / F$ was calculated after background subtraction. The decay time constants of the dendritic fluorescence transients $(\tau=$ $834 \pm 79 \mathrm{msec} ; 40-100 \mu \mathrm{m} ; n=14$ ) were not significantly different from those measured with fura-2 $(\tau=707 \pm 41 \mathrm{msec} ; n=17 ; p>0.2)$. Although this may suggest that $\Delta F / F$ is linearly related to the $\mathrm{Ca}^{2+}$ concentration, we cannot exclude a partial saturation of Oregon Green. This would imply a slight underestimation of the $\mathrm{Ca}^{2+}$ transient and, hence, of the effect of nifedipine.

Chemicals. 8-hydroxy-2-dipropylamino-tetralin (OH-DPAT), $(S)-\alpha$ methyl-4-carboxyphenyl-glycine (MCPG), and D(-)-2-amino-5phosphonopentanoic acid (D-AP-5) were obtained from Tocris, and TTX and $\omega$-conotoxin GVIA were obtained from Alomone (Jerusalem, Israel). All other chemicals were from Merck, Sigma, Riedel-de Haen, or Gerbu. Stock solutions were made in distilled water or dimethylsulfoxide (for nifedipine, concentration of dimethylsulfoxide in the final solution, $\leq 0.1 \%$ ). $\omega$-conotoxin GVIA was coapplied with $1 \mathrm{mg} / \mathrm{ml}$ bovine serum albumin (BSA) to prevent unspecific binding of the peptide toxins. Agonists and antagonists were applied by bath perfusion with the exception of $\omega$-conotoxin GVIA. For this substance, the bath perfusion was interrupted, and the toxin was applied manually in the recording chamber with a pipette. Neither the interruption of the perfusion nor the application of extracellular solution alone with BSA via a pipette had any effect on $\mathrm{Ba}^{2+}$ currents or basal synaptic transmission. Nifedipine was protected from light.

\section{RESULTS}

Whole-cell current-clamp recordings from CA1 pyramidal cells were made, and EPSPs were evoked by electrical stimulation of Schaffer collaterals (Fig. $1 A$ ). The cells were held at a membrane potential of -68 to $-70 \mathrm{mV}$, near the average resting potential $(-68.6 \pm 0.3 \mathrm{mV} ; n=58)$. A robust associative LTD was induced by asynchronous pairing of extracellular Schaffer-collateral stimulation with a short postsynaptic current injection generating an action potential $20 \mathrm{msec}$ before the EPSP (Fig. 1A,B). Time intervals of 10-20 msec have been shown to be maximally effective for the induction of associative LTD (Levy and Steward, 1983; Markram et al., 1997; Bi and Poo, 1998). The pairing was repeated 360 times at a frequency of 0.3 or $1 \mathrm{~Hz}$. This asynchronous pairing stimulation (APS) reduced the EPSP amplitude to $42.7 \pm 1.8 \%$ ( $n=17 ; p<0.001)$ of the control value, measured $15-20$ min after the induction protocol (Fig. 1C,D). As shown in Figure 2, 360 action potentials or EPSPs alone at $1 \mathrm{~Hz}$ did not induce significant alterations in EPSP amplitude (action potentials alone: $93.8 \pm$ $5.1 \%, n=3 ; p>0.5$; EPSPs alone: $103.4 \pm 4.9 \%$ of control EPSP amplitude, $n=3 ; p>0.5)$. Thus, this form of LTD is associative and dependent on the asynchronous activity of both presynaptic and postsynaptic neurons.

\section{Associative LTD is dependent on metabotropic glutamate receptors}

To investigate the induction mechanisms of associative LTD, we first examined the contribution of metabotropic glutamate receptors (Fig. $3 A$ ). In the presence of $500 \mu \mathrm{M}$ MCPG, an antagonist of metabotropic glutamate receptors, the induction of associative 
A

Figure 1. Associative LTD induced by asynchronous pairing of presynaptic and postsynaptic action potentials in CA1 pyramidal neurons. $A$, Current-clamp whole-cell recording from a CA1 pyramidal neuron. EPSPs were evoked by extracellular stimulation of the Schaffer collateral pathway with $200 \mu$ sec voltage pulses applied through the stimulation pipette (inset). The EPSP amplitude was significantly decreased by asynchronous pairing of presynaptic and postsynaptic activity. Traces shown were taken immediately before and $15 \mathrm{~min}$ after asynchronous pairing. $B$, For the APS, a single action potential was evoked in the postsynaptic CA1 pyramidal neuron by current injection ( $700 \mathrm{pA}, 5 \mathrm{msec})$. Twenty milliseconds after the onset of the current injection, an EPSP was evoked. This pairing was repeated 360 times at a frequency of 0.3 or $1 \mathrm{~Hz}$. $C$, The EPSP amplitude during a single representative experiment is plotted against time. $D$, The mean EPSP amplitude is plotted against time $(n=17)$. The APS induction paradigm was applied at the time indicated by the arrow.

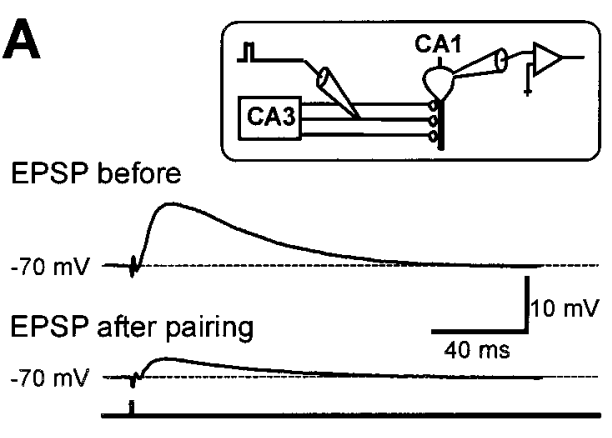

B
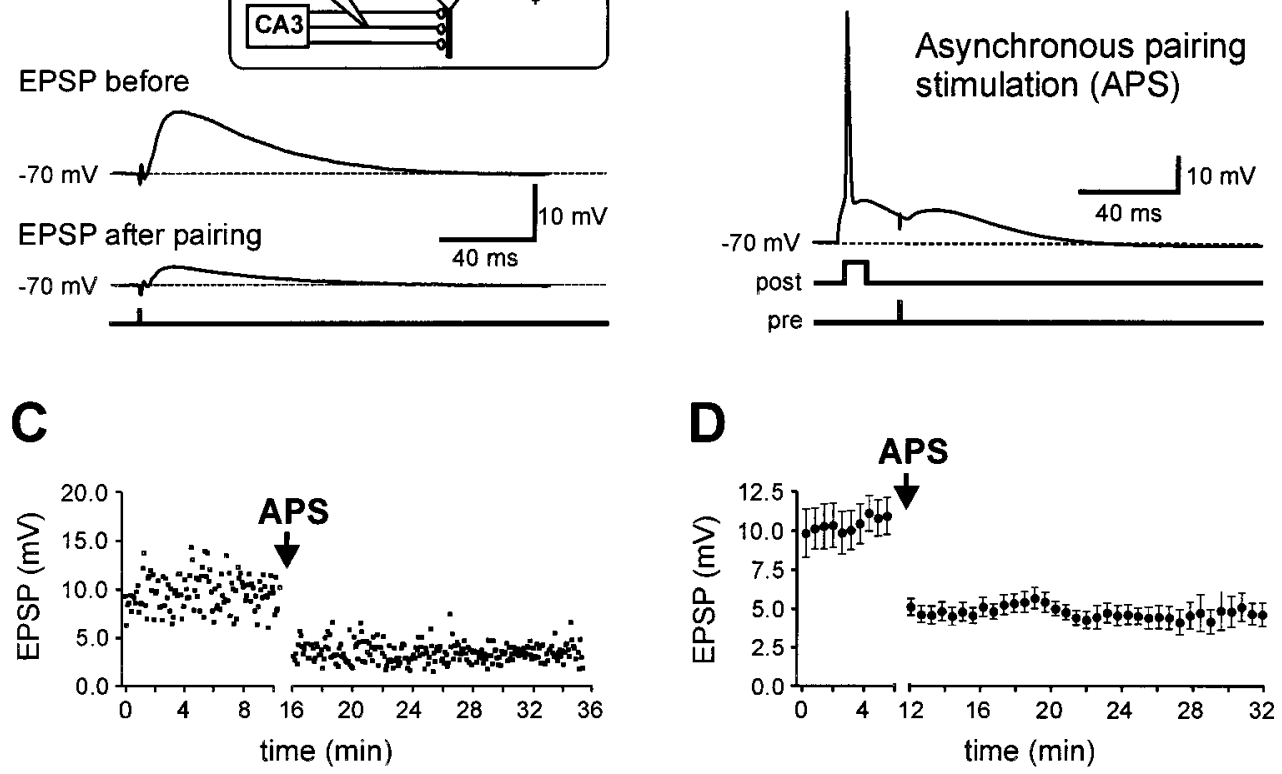

LTD was inhibited $(105.3 \pm 3.6 \%$ of control EPSP amplitude, $n=$ $6 ; p>0.1)$. By contrast, the NMDAR antagonist D-AP-5 $(50 \mu \mathrm{M})$ was without effect on the synaptic depression (Fig. $3 B$ ). In the presence of D-AP-5, the EPSP amplitude was depressed to $45.5 \pm$ $3.5 \%(n=6 ; p<0.001)$, similar to the control condition. In addition, D-AP-5 had no significant effects on EPSP peak amplitude $(8.6 \pm 1.2 \mathrm{mV}$ in control solution vs $8.5 \pm 1.2 \mathrm{mV}$ in D-AP-5, $n=$ $11 ; p>0.5)$ and EPSP decay time constant $(11.0 \pm 11.1 \%$ decrease, $n=11 ; p>0.05)$. These results are consistent with a minimal contribution of NMDARs to basal synaptic transmission in CA1 pyramidal cells near the resting membrane potential (Herron et al., 1986; Cash and Yuste, 1999). Thus, under our experimental conditions the NMDARs do not significantly contribute to both basal synaptic transmission and induction of associative LTD.

A standard protocol for the induction of LTD is the application of prolonged LFS of presynaptic neurons (e.g., 900 pulses at $1 \mathrm{~Hz}$; Dudek and Bear, 1992). Using this protocol we could only induce long-term depression if the postsynaptic cell was slightly depolarized to $-62 \mathrm{mV}$, but not at the resting membrane potential of -68 to $-70 \mathrm{mV}$. As this potential was closer to firing threshold we used smaller initial EPSP amplitudes (range, $1-4 \mathrm{mV}$ at $-70 \mathrm{mV}$ ) to avoid postsynaptic spiking during LFS induction (Fig. 3C, inset). The LFS protocol induced a depression of the EPSPs to $40.9 \pm$ $2.5 \%$ of the control amplitude $(n=8 ; p<0.001$; Fig. $3 C)$. Application of D-AP-5 $(50 \mu \mathrm{M})$ inhibited the induction of LFS-induced LTD (EPSP amplitude was $100.7 \pm 10.4 \%$ after $15 \min , n=4 ; p>$ 0.5 , Fig. 3D). Thus, LFS induces an NMDAR-dependent LTD, consistent with previous reports (Dudek and Bear, 1992; Oliet et al., 1997). In addition, the voltage dependence of the LFS-induced NMDAR LTD was similar to that described previously (Debanne et al., 1996; Goda and Stevens, 1996; Oliet et al., 1997; Fitzsimonds et al., 1997). In conclusion, associative pairing selectively induces mGluR-dependent LTD, whereas low-frequency stimulation leads to NMDAR-dependent LTD.

\section{Associative LTD is dependent on activation of voltage-gated $\mathrm{Ca}^{2+}$ channels}

Previous studies showed that the induction of both mGluR-and NMDAR-dependent LTD is blocked by the $\mathrm{Ca}^{2+}$ chelator BAPTA (Mulkey and Malenka, 1992; Oliet et al., 1997). To examine postsynaptic $\mathrm{Ca}^{2+}$ signaling in associative LTD, we measured $\mathrm{Ca}^{2+}$ transients in the soma and apical dendrites of CA1 pyramidal neurons induced by single backpropagating action potentials using
$0.1 \mathrm{~mm}$ fura-2. After a single action potential, the dendritic $\mathrm{Ca}^{2+}$ concentration increased by $148 \pm 14 \mathrm{~nm}$ from a resting value of $46 \pm 5 \mathrm{~nm}$ (distance from soma $40-100 \mu \mathrm{m} ; n=17$; Fig. $4 A$ ). This transient increase in $\mathrm{Ca}^{2+}$ concentration decayed to initial baseline levels with a time constant of $707 \pm 41 \mathrm{msec}$.

Application of $1 \mu \mathrm{M} \omega$-conotoxin GVIA, an irreversible blocker of $\mathrm{N}$-type $\mathrm{Ca}^{2+}$ channels, reduced the dendritic $\mathrm{Ca}^{2+}$ transients by $38.3 \pm 4.6 \%(n=6 ; 40-100 \mu \mathrm{m}$; Fig. $4 A, B)$. This indicates that $\mathrm{N}$-type $\mathrm{Ca}^{2+}$ channels are effectively opened by single backpropagating action potentials. To assess the contribution of L-type $\mathrm{Ca}^{2+}$ channels, we examined the effects of $10 \mu \mathrm{M}$ nifedipine. Because nifedipine is very light-sensitive, we used $0.1 \mathrm{~mm}$ Oregon Green instead of fura-2 (see Materials and Methods). A single action potential evoked a transient fluorescence increase of $\Delta F / F=$ $108.5 \pm 13 \%(n=14)$. Application of $10 \mu \mathrm{M}$ nifedipine reduced the dendritic $\mathrm{Ca}^{2+}$ transients by $19.4 \pm 1.6 \%(n=5 ; 40-100 \mu \mathrm{m}$; Fig. $4 B)$. Thus, a single backpropagating action potential induces a reliable $\mathrm{Ca}^{2+}$ influx through voltage-gated $\mathrm{Ca}^{2+}$ channels in the proximal apical dendrite of CA1 pyramidal neurons, with a substantial amount carried by $\mathrm{N}$ - and L-type $\mathrm{Ca}^{2+}$ channels.

To test the involvement of these channels in LTD induction, we applied the LTD induction protocol in the presence of $\mathrm{Ca}^{2+}$ channel antagonists. When $0.5 \mu \mathrm{M} \omega$-conotoxin GVIA was applied during basal synaptic transmission, the EPSP amplitude was reduced from $16.8 \pm 2.3 \mathrm{mV}$ to $5.8 \pm 1.4 \mathrm{mV}(n=9$; Fig. $4 C)$, indicating the inhibition of presynaptic $\mathrm{N}$-type $\mathrm{Ca}^{2+}$ channels that mediate neurotransmitter release (Dunlap et al., 1995). As a higher stimulus intensity was used in these experiments, EPSPs in the presence $\omega$-conotoxin were sufficiently large to examine the effects of subsequent pairing. Under these conditions the asynchronous pairing protocol failed to induce significant depression of the EPSP amplitude (102 $\pm 5.0 \%$ of control EPSP amplitude, $n=9 ; p>0.5)$. Although we cannot exclude a contribution of presynaptic N-type $\mathrm{Ca}^{2+}$ channels, these results suggest that $\mathrm{Ca}^{2+}$ influx through postsynaptic N-type channels is required for the induction of associative LTD. Similarly, we tested the involvement of L-type $\mathrm{Ca}^{2+}$ channels in LTD induction (Fig. 4D). In contrast to $\omega$-conotoxin, nifedipine did not reduce the initial EPSP amplitude. However, nifedipine markedly reduced the amount of LTD (reduction of EPSP amplitude to $89.6 \pm 4.3 \%, n=7 ; p>0.5)$. Thus, postsynaptic $\mathrm{Ca}^{2+}$ influx through voltage-gated $\mathrm{Ca}^{2+}$ channels is necessary for the induction of associative LTD. 
A
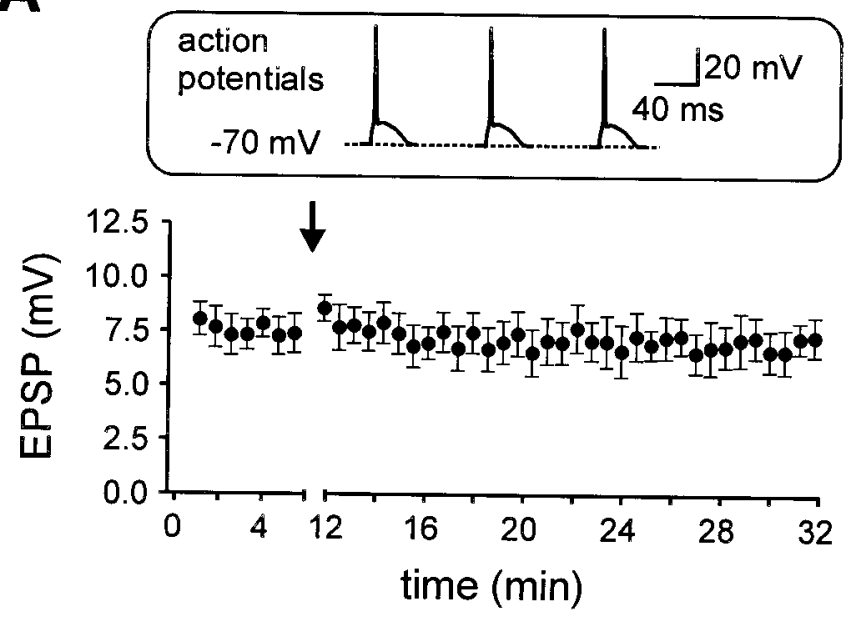

B

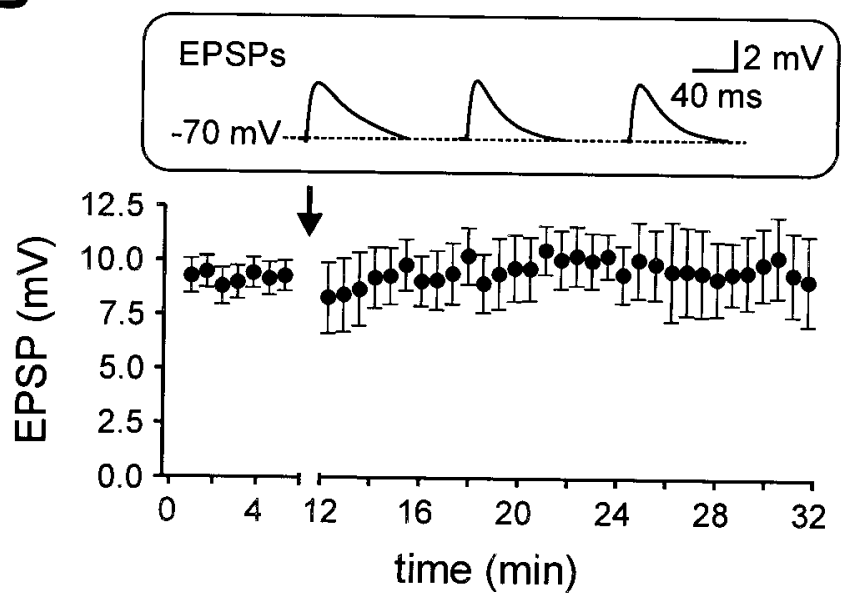

Figure 2. Postsynaptic action potentials or EPSPs alone are not sufficient to induce LTD. $A$, The mean EPSP amplitude is plotted against time. Three hundred sixty action potentials were evoked in the postsynaptic cell at a frequency of $1 \mathrm{~Hz}$ from a membrane potential of $-70 \mathrm{mV}$. This protocol did not change the EPSP amplitude $(n=3)$. $B$, Three hundred sixty EPSPs at a membrane potential of $-70 \mathrm{mV}$, as shown in the inset, evoked at a frequency of $1 \mathrm{~Hz}$ did not change the EPSP amplitude $(n=3)$. The induction paradigms were applied at the times indicated by the arrows. Insets represent the first three sweeps of the induction paradigm of a representative experiment.

\section{Modulation of postsynaptic $\mathrm{N}$-type $\mathrm{Ca}^{2+}$ channels inhibits associative LTD}

OH-DPAT, a selective agonist of 5-hydroxytryptamine (5-HT) $)_{1 \mathrm{~A}}$ receptors, is known to inhibit $\mathrm{N}$-type $\mathrm{Ca}^{2+}$ channels in cortical pyramidal neurons by activation of a $\mathrm{G}_{\mathrm{i} / \mathrm{o}-\mathrm{p}}$ protein (Foehring, 1996). Immunocytochemical analysis revealed a high density of $5-\mathrm{HT}_{1 \mathrm{~A}}$ receptors in the hippocampal CA1 region and further suggested an exclusively postsynaptic location (Kia et al., 1996). Thus, we considered OH-DPAT as a selective inhibitor of postsynaptic N-type $\mathrm{Ca}^{2+}$ channels. As a first experimental step, we examined the effect of OH-DPAT on the action potential-induced $\mathrm{Ca}^{2+}$ transient (Fig. $5 A)$. Application of $1 \mu \mathrm{M}$ OH-DPAT reduced the dendritic $\mathrm{Ca}^{2+}$ transients by $25.6 \pm 2.7 \%(n=5 ; 40-100 \mu \mathrm{m})$. This is consistent with the previously reported reduction of burst-induced $\mathrm{Ca}^{2+}$ transients by $10 \mu \mathrm{M} 5-\mathrm{HT}$ in CA1 pyramidal neurons (Sandler and Ross, 1999).

The reduction in the dendritic $\mathrm{Ca}^{2+}$ transient by OH-DPAT could be attributable to a direct inhibition of $\mathrm{Ca}^{2+}$ channels or a reduction in the amplitude of the backpropagating action potential, or both. For $10 \mu \mathrm{M}$ 5-HT a slight reduction of the amplitude of the backpropagating action potentials was reported (Sandler and Ross, 1999). To distinguish between these possibilities, we blocked $\mathrm{Na}^{+}$ and $\mathrm{K}^{+}$channels (see Materials and Methods) and examined $\mathrm{Ca}^{2+}$ channels in isolation in the whole-cell voltage-clamp configuration using $2 \mathrm{mM} \mathrm{Ba}^{2+}$ as charge carrier (Fig. $5 B$ ). The application of 1 $\mu \mathrm{M}$ OH-DPAT reduced the $\mathrm{Ba}^{2+}$ currents to $72.9 \pm 10.9 \%(n=8$; $p<0.01)$. In the presence of $\omega$-conotoxin GVIA the $\mathrm{Ba}^{2+}$ currents were reduced to $45.8 \pm 6.6 \%(n=4)$. Subsequent to the application of $\omega$-conotoxin, the modulation by OH-DPAT was completely absent, indicating a selective modulation of $\mathrm{N}$-type $\mathrm{Ca}^{2+}$ channels by $5-\mathrm{HT}_{1 \mathrm{~A}}$ receptors. In the presence of $10 \mu \mathrm{M}$ nifedipine (84.7 \pm $7.0 \%$ of control; $n=4)$, however, there was still a substantial reduction of the $\mathrm{Ba}^{2+}$ currents by OH-DPAT $(57.0 \pm 3.9 \%$ of control; $p<0.01)$.

To examine possible effects of $1 \mu \mathrm{M}$ OH-DPAT on action potential backpropagation, we made double recordings from the soma and the apical dendrite of CA1 pyramidal cells at distances of 64-192 $\mu \mathrm{m}$ from the soma (Fig. 5C). The shape of the dendritic and somatic action potential in $1 \mu \mathrm{M}$ OH-DPAT was very similar to control conditions. The resting membrane potential was slightly hyperpolarized by $-1.0 \pm 0.2 \mathrm{mV}$ at the dendrite and by $-0.9 \pm$ $0.2 \mathrm{mV}$ at the soma ( $p<0.05$; six double recordings). As shown in Figure $5 D$, the action potential amplitude in the presence of $1 \mu \mathrm{M}$ OH-DPAT was virtually identical to control conditions (101.2 \pm $0.9 \%$ of control, $n=6 ; p>0.1$ ). Furthermore no significant change in half width of the dendritic AP $(102.1 \pm 2.1 \%$ of control; $p>0.1)$ or the propagation velocity $(98.3 \pm 3.2 \%$ of control; $p>0.1$; Fig. $5 D$ ) was observed. In conclusion, these results indicate that the reduction of action potential-induced $\mathrm{Ca}^{2+}$ transients of $1 \mu \mathrm{M}$ OH-DPAT is attributable to a direct modulation of postsynaptic N-type $\mathrm{Ca}^{2+}$ channels and not to an inhibition of dendritic backpropagation.

If postsynaptic $\mathrm{N}$-type $\mathrm{Ca}^{2+}$ channels are necessary for induction of associative LTD (Fig. 4C) and if these channels are selective targets for modulation via 5- $\mathrm{HT}_{1 \mathrm{~A}}$ receptors (Fig. 5), then $\mathrm{OH}$ DPAT should affect LTD induction. We first tested the effect of 1 $\mu \mathrm{M}$ OH-DPAT on basal synaptic transmission, and we found that the peak EPSP amplitude remained unchanged (Fig. 6A; $95.8 \pm$ $6.4 \%$ of control, $n=11 ; p>0.5$ ). This allowed us to use OH-DPAT as a tool to inhibit selectively postsynaptic N-type $\mathrm{Ca}^{2+}$ channels. In the presence of $1 \mu \mathrm{M}$ OH-DPAT, application of the asynchronous pairing paradigm failed to induce associative LTD (102.8 \pm $4.9 \%$ of control, $n=11 ; p>0.5$; Fig. $6 B, C$ ). These results indicate that the $\mathrm{Ca}^{2+}$ influx via postsynaptic $\mathrm{N}$-type channels is necessary for induction of associative LTD and that the G-protein-mediated modulation of these channels strongly controls this form of synaptic plasticity.

\section{DISCUSSION}

Our results show that associative LTD at the Schaffer collateralCA1 pyramidal cell synapse can be induced reliably by asynchronous pairing of EPSPs with preceding postsynaptic action potentials. The induction was dependent on both mGluRs and postsynaptic voltage-gated $\mathrm{Ca}^{2+}$ channels. In particular, we show a direct involvement of $\mathrm{N}$-type $\mathrm{Ca}^{2+}$ channels in synaptic plasticity. The modulation of postsynaptic $\mathrm{N}$-type $\mathrm{Ca}^{2+}$ channels by $5-\mathrm{HT}_{1 \mathrm{~A}}$ receptors was sufficient to inhibit associative LTD induced by asynchronous pairing.

\section{Associative LTD is dependent on mGluRs}

The induction of LTD by the associative paring protocol was blocked by the mGluR antagonist MCPG, similar to the previously described mGluR LTD (Bolshakov and Siegelbaum, 1994; Oliet et al., 1997; Otani and Connor, 1998). Although we did not use subtype-specific antagonists, it is likely that the depression is mediated by mGluR5. Immunocytochemical evidence indicates that mGluR5 is the most abundant metabotropic glutamate receptor present on the postsynaptic CA1 pyramidal cells (Shigemoto et al., 1997). Furthermore, there is evidence for the involvement of the phospholipase C (PLC) signal transduction pathway in mGluR 
A

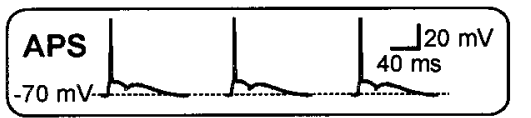

B

\section{MCPG}

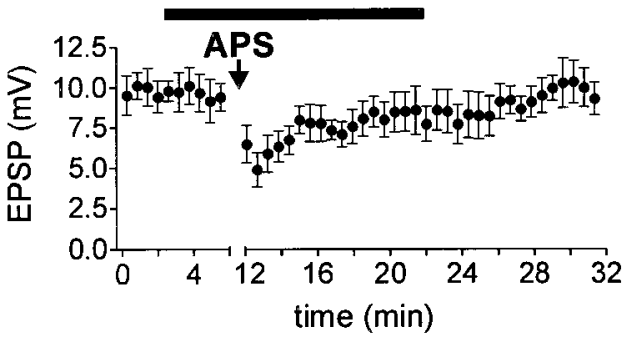

on activation of metabotropic glutamate receptors. $A$, The mean EPSP amplitude is plotted against time. In the presence of $500 \mu \mathrm{M}$ MCPG, an antagonist of metabotropic glutamate receptors, the associative LTD was inhibited $(n=6)$. $B$, The NMDAR antagonist D-AP-5 $(50 \mu \mathrm{M})$ was without effect on both basal synaptic transmission and the induction of associative LTD $(n=6)$. $C$, Nine hundred EPSPs at a membrane potential of $-62 \mathrm{mV}$ (inset), evoked at a frequency of $1 \mathrm{~Hz}$ (indicated by the arrow) reliably depressed the EPSP amplitude $(n=8)$. $D$, LFS-induced LTD was blocked by the application of 50 $\mu \mathrm{M}$ D-AP-5 $(n=4)$. Insets in $A$ and $C$ represent the first three sweeps of the induction paradigm of a representative experiment. Horizontal bars indicate the presence of the MCPG and D-AP-5, respectively.

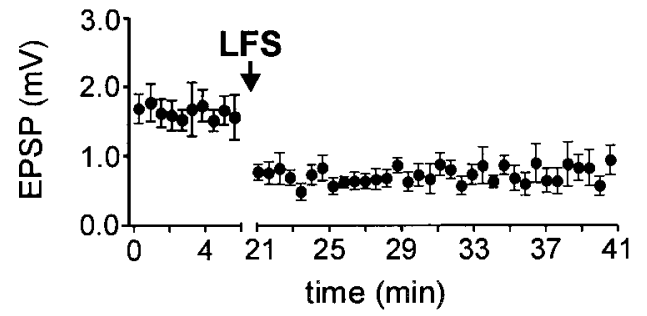

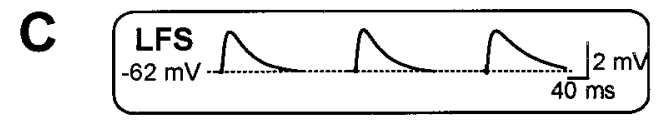
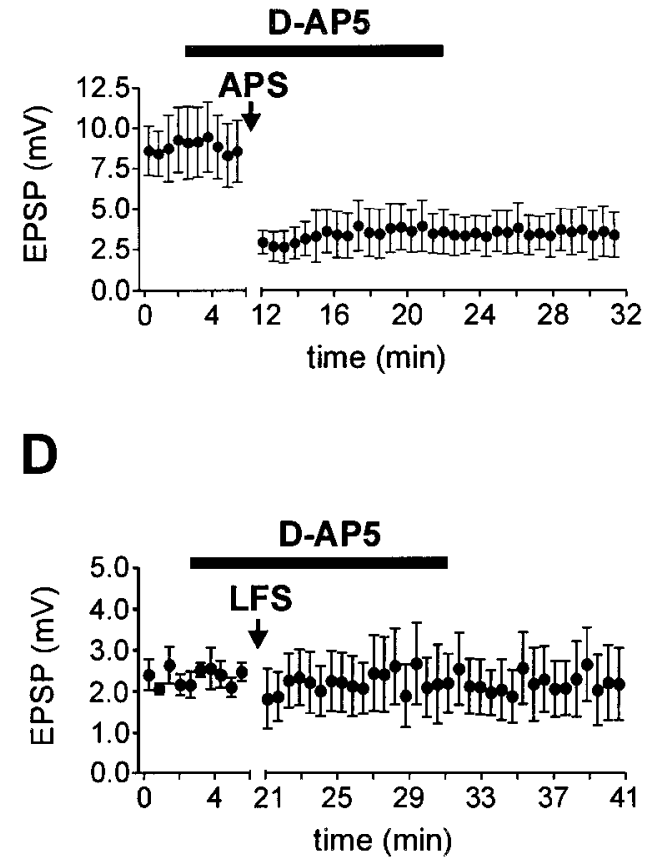

LTD, consistent with the activation of group 1 mGluRs (Oliet et al., 1997; Otani and Connor, 1998).

The induction mechanism of associative LTD appeared to be different from that of LFS-induced LTD, which was largely blocked by the NMDAR antagonist D-AP-5 (Fig. 3), consistent with previous studies (Dudek and Bear, 1992; Mulkey and Malenka, 1992). The coexistence of two different forms of LTD in hippocampal pyramidal cells was described in detail by Oliet et al. (1997). In bath solutions containing $2.5 \mathrm{mM} \mathrm{Ca}^{2+}$ and $1.3 \mathrm{mM} \mathrm{Mg}^{2+}$, LFS primarily induced NMDAR LTD. In $4 \mathrm{mM} \mathrm{Ca}^{2+}$ and $4 \mathrm{mM} \mathrm{Mg}^{2+}$, however, an additional NMDAR-independent form of LTD was induced, which was dependent on mGluRs and voltage-gated $\mathrm{Ca}^{2+}$ channels (Oliet et al., 1997). Because associative LTD in acute hippocampal slices is dependent on mGluRs but not on NMDARs,
Figure 4. Associative LTD is dependent on $\mathrm{Ca}^{2+}$ influx via both, voltagegated $\mathrm{N}$ - and $\mathrm{L}$-type $\mathrm{Ca}^{2+}$ channels. $A$, Fluorescence image of a CA1 pyramidal neuron filled with $0.1 \mathrm{~mm}$ fura-2 (380 $\mathrm{nm}$ excitation). Rectangles indicate somatic and dendritic ROIs from where $\mathrm{Ca}^{2+}$ transients were recorded with high time resolution $(100 \mathrm{~Hz}$, traces on the right). The action potential-induced $\mathrm{Ca}^{2+}$ transients were reduced in the presence of $1 \mu \mathrm{M} \omega$-conotoxin GVIA ( $\omega$-con, N-type blocker). $B$, The bar graph summarizes the mean inhibition of the $\mathrm{Ca}^{2+}$ transient by $\omega$-conotoxin GVIA $(n=6)$ obtained with $0.1 \mathrm{~mm}$ fura-2 and $10 \mu \mathrm{M}$ nifedipine $(n=5$; L-type blocker) obtained with $0.1 \mathrm{~mm}$ Oregon Green (see Materials and Methods). Dendritic ROIs were located in the stratum radiatum at a distance of $\sim 0-40 \mu \mathrm{m}$ or $40-100 \mu \mathrm{m}$ from the soma. $C$, Application of $0.5 \mu \mathrm{M}$ $\omega$-conotoxin GVIA $(n=9)$ reduced basal synaptic transmission and prevented the induction of LTD by APS. $D$, A $10 \mu \mathrm{M}$ concentration of nifedipine did not affect basal transmission but similarly inhibited LTD induction $(n=7)$. Voltage traces in $C$ and $D$ are EPSPs from a single representative experiment, respectively, at the times indicated by the asterisks.
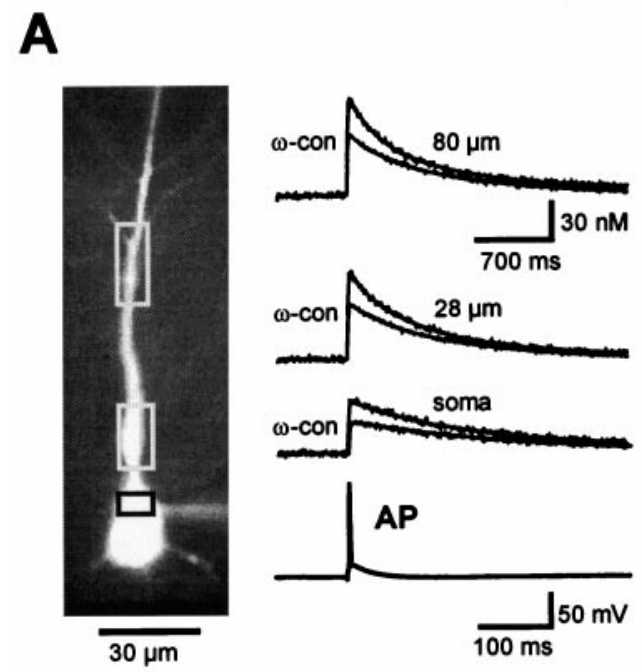

B

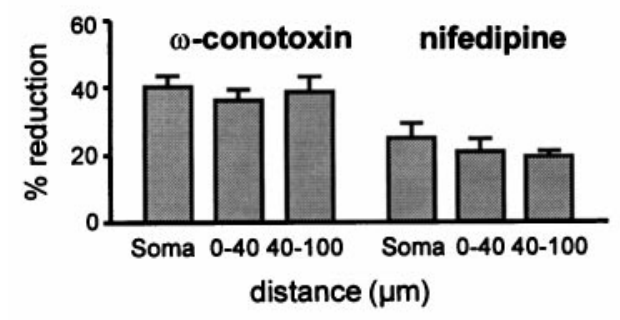

C

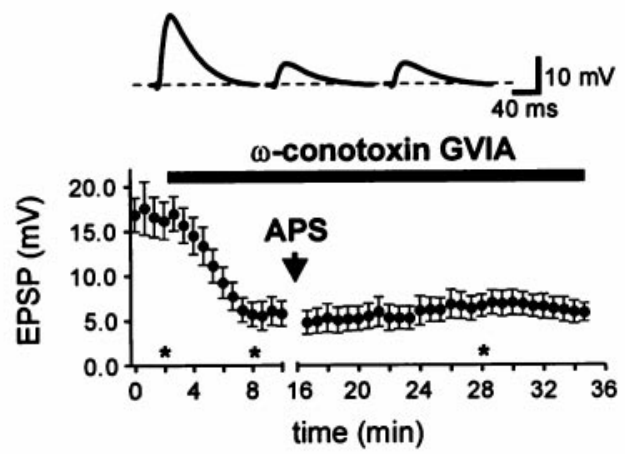

D

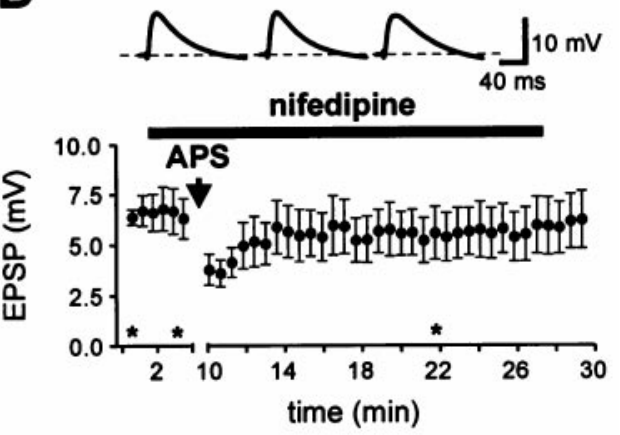


A
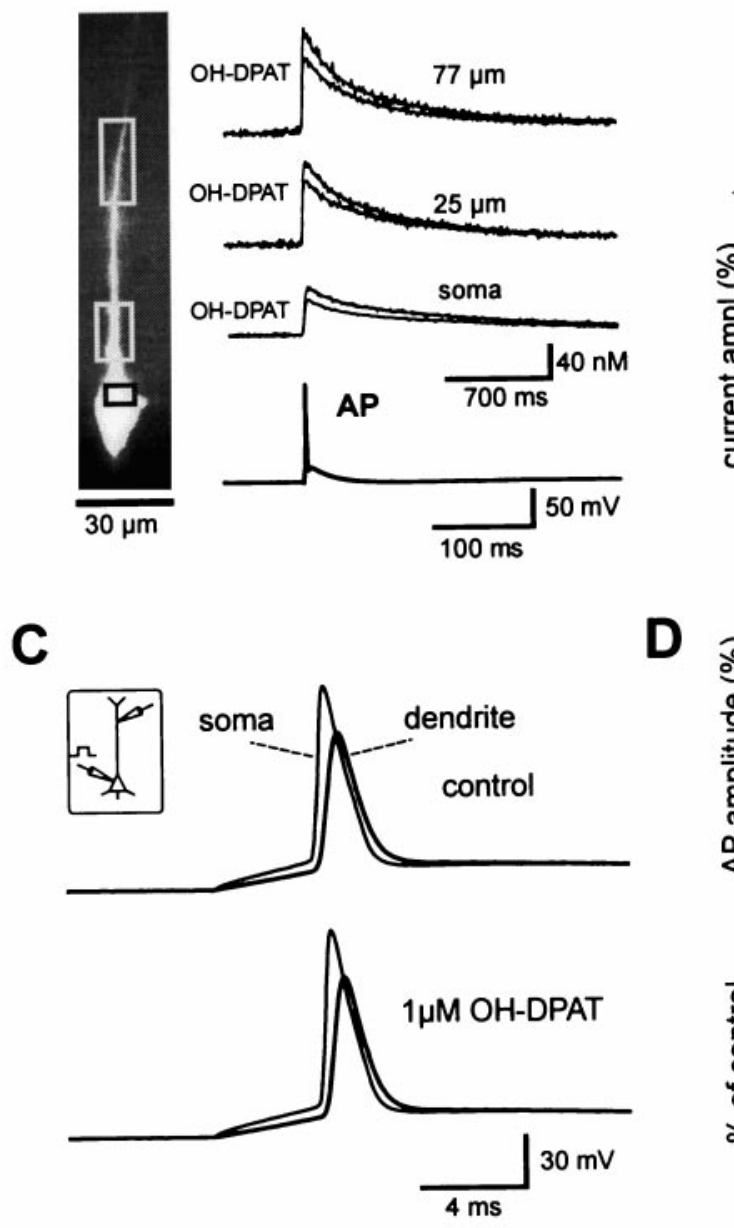

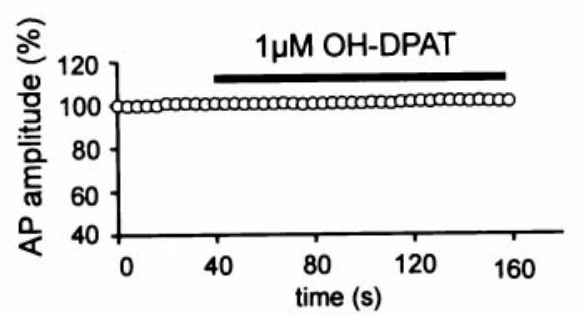

B

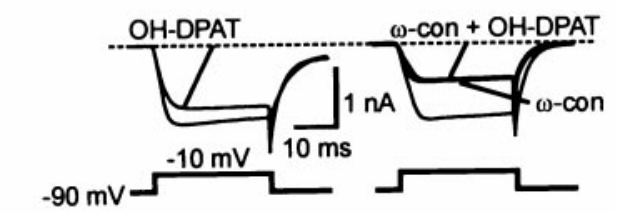

Figure 5. Selective suppression of N-type $\mathrm{Ca}^{2+}$ channels by $5-\mathrm{HT}_{1 \mathrm{~A}}$ receptors. $A$, Action potential-induced $\mathrm{Ca}^{2+}$ transients recorded from the CA1 pyramidal neuron shown on the left $(0.1$ $\mathrm{mm}$ fura-2), in control conditions, and in the presence of the $5-\mathrm{HT}_{1 \mathrm{~A}}$ receptor agonist OH-DPAT $(1 \mu \mathrm{M})$. B , Wholecell voltage-clamp recordings from CA1 pyramidal neurons. Modulation of $\mathrm{Ca}^{2+}$ channels was analyzed using 30 msec voltage steps from a holding potential of -90 to $-10 \mathrm{mV}$ and $\mathrm{Ba}^{2+}$ as a charge carrier in the bath. The traces show currents in control and after application of $1 \mu \mathrm{M}$ OH-DPAT (left traces) or OH-DPAT in the presence of $0.5 \mu \mathrm{M}$ $\omega$-conotoxin GVIA (right traces), respectively. The bar graph summarizes the mean of $n=8$ (OH-DPAT), $n=4$ $(\omega$-conotoxin plus OH-DPAT), and $n=$ 4 (nifedipine plus OH-DPAT) experiments. $C$, Double recording from the soma and the apical dendrite of a CA1 pyramidal neuron (distance between recording sites was $192 \mu \mathrm{m}$; inset). Somatic current injection ( $900 \mathrm{pA}, 5 \mathrm{msec})$ evoked backpropagating action potentials, which did not significantly change after application of $1 \mu \mathrm{M}$ OH-DPAT. $D$, The amplitude of the dendritic action potential is plotted against time (top panel, 6 double recordings, normalized to initial value). The average distance was $110 \pm 22 \mu \mathrm{m}$. The bar graph (bottom panel) summarizes the effect of 1 $\mu \mathrm{M}$ OH-DPAT on somatic and dendritic AP amplitude, on the half width of the dendritic AP and on the propagation velocity relative to control $(n=6)$. the asynchronous pairing protocol might be the most physiological way to selectively induce the mGluR-dependent LTD.

Thus, two mechanistically distinct forms of LTD coexist in hippocampal pyramidal cells, which can be induced selectively, depending on pyramidal cell firing during network activity (O’Keefe and Reece, 1993). Prolonged presynaptic activity without any postsynaptic spiking may decrease the EPSP amplitude via nonassociative LTD dependent on NMDARs, whereas EPSPs that occur repeatedly at a certain time delay with respect to postsynaptic action potentials will be depressed by associative LTD dependent on mGluRs.

\section{Associative LTD is dependent on activation of postsynaptic $\mathrm{Ca}^{2+}$ channels}

The mGluR LTD induced by associative pairing could be blocked by the inhibition of either L- or N-type $\mathrm{Ca}^{2+}$ channels (Fig. 4). These channels were reliably activated during single backpropagating action potentials (Fig. $4 B$ ). This is consistent with the localization of $\mathrm{L}-$ and $\mathrm{N}$-type $\mathrm{Ca}^{2+}$ channels on soma and apical dendrites of CA1 pyramidal neurons (Westenbroek et al., 1992; Kavalali et al., 1997; Magee, 1999) and with cell-attached patch recordings from these dendrites (Magee and Johnston, 1995). In addition, other types of $\mathrm{Ca}^{2+}$ channels are expressed in CA1 pyramidal cells, including P-, R-, and T-type channels (Kavalali et al., 1997). They may be responsible for the $\omega$-conotoxin- and nifedipineresistant $\mathrm{Ca}^{2+}$-influx.

It may seem surprising that a small $(20-40 \%)$ reduction of the spatially averaged dendritic $\mathrm{Ca}^{2+}$ transient was sufficient to substantially reduce or block the associative LTD. However, the $\mathrm{Ca}^{2+}$ concentration at $\mathrm{Ca}^{2+}$-dependent effector molecules may be very different from the measured $\mathrm{Ca}^{2+}$ transients. The peak amplitude of the $\mathrm{Ca}^{2+}$ transient in submembrane cytoplasmic compartments could be much higher because of clustering of $\mathrm{Ca}^{2+}$ channels and local saturation of $\mathrm{Ca}^{2+}$ buffers (Helmchen et al., 1996). If, for example, N-type $\mathrm{Ca}^{2+}$ channels were colocalized with molecules involved in LTD induction, then our data would represent a lower estimate for the contribution of these channels to local $\mathrm{Ca}^{2+}$ signals near these effector molecules. Such a colocalization could occur in dendritic spines, where action potential-induced $\mathrm{Ca}^{2+}$ transients have larger amplitudes than in nearby parent dendrites (Majewska et al., 2000).

Our results and previous reports (Bolshakov and Siegelbaum, 1994; Oliet et al., 1997; Otani and Connor, 1998) converge on the conclusion that postsynaptic $\mathrm{Ca}^{2+}$ influx is essential for LTD induction. However, the target molecules for $\mathrm{Ca}^{2+}$ remain to be identified. $\mathrm{A} \mathrm{Ca}^{2+}$-dependent phosphatase is unlikely to be involved, because the phosphatase inhibitor microcystin does not affect mGluR LTD (Oliet et al., 1997). An involvement of $\mathrm{Ca}^{2+}$ dependent isoforms of PKC is more likely, because PKC inhibitory peptide blocks mGluR LTD (Oliet et al., 1997; Otani and Connor, 1998). Because some PKC isoforms are activated by both diacylglycerol and $\mathrm{Ca}^{2+}$ (Nishizuka, 1992), they could operate as molecular coincidence detectors, onto which the activation of voltagegated $\mathrm{Ca}^{2+}$ channels and group $1 \mathrm{mGluRs}$ converge. This would explain the need for both postsynaptic action potentials and the release of glutamate for induction of associative LTD.

\section{Modulation of $\mathrm{N}$-type $\mathrm{Ca}^{2+}$ channels and LTD}

The involvement of $\mathrm{N}$-type $\mathrm{Ca}^{2+}$ channels in synaptic plasticity is difficult to assess because of the inhibition of basal synaptic trans- 
A

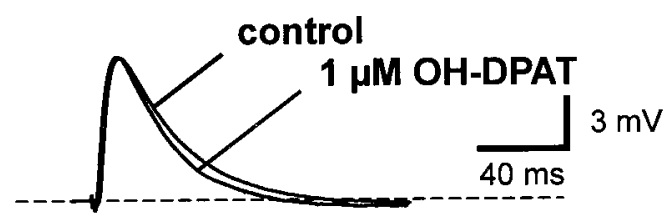

B

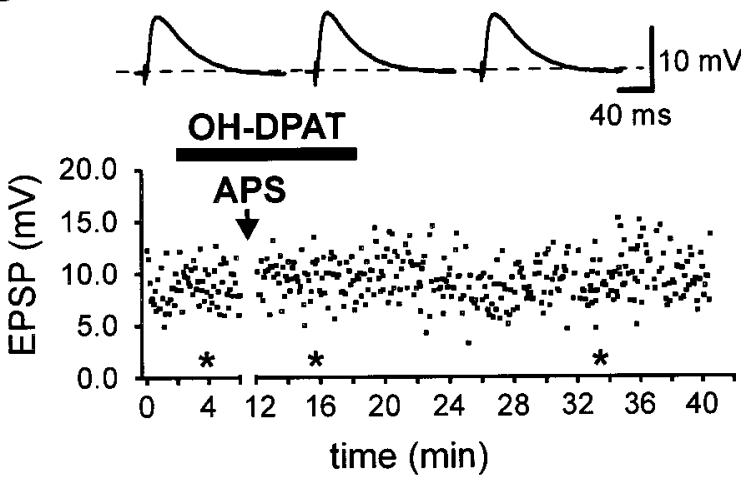

C

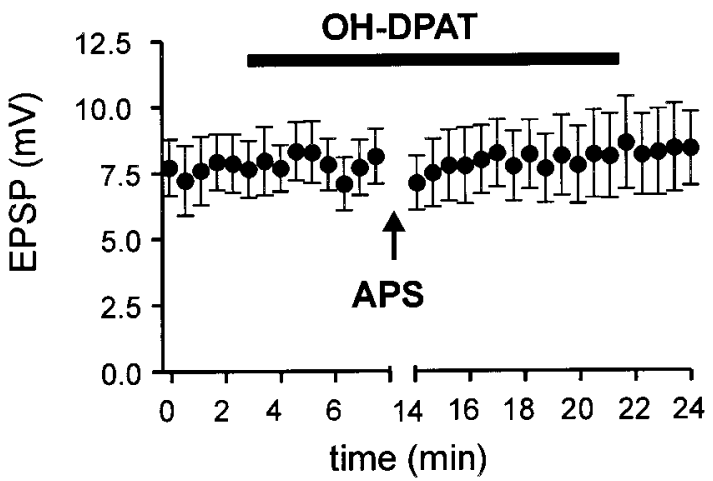

Figure 6. Block of associative LTD by inhibition of postsynaptic N-type $\mathrm{Ca}^{2+}$ channels via $5-\mathrm{HT}_{1 \mathrm{~A}}$ receptors. $A$, The application of $1 \mu \mathrm{M} \mathrm{OH}-$ DPAT did not affect the EPSP amplitude during basal transmission. $B$, The EPSP amplitude during a single representative experiment is plotted against time. Voltage traces on top are EPSPs from a single representative experiment obtained at the times indicated by the asterisks. $C$, The mean EPSP amplitude is plotted against time $(n=11)$. Note that the EPSP amplitude remains constant during application of OH-DPAT. The induction of associative LTD by APS, however, was completely blocked.

mission by $\omega$-conotoxin GVIA. No selective postsynaptic N-type channel antagonist is available yet. In our study, the selective $5-\mathrm{HT}_{1 \mathrm{~A}}$ agonist OH-DPAT is a valuable tool to distinguish between presynaptic and postsynaptic N-type channels. A $1 \mu \mathrm{M}$ concentration of OH-DPAT, which selectively inhibits postsynaptic $\mathrm{N}$-type channels by G-protein modulation, was sufficient to block LTD induction. The dependence of associative LTD on N-type $\mathrm{Ca}^{2+}$ channels might be important, because $\mathrm{N}$-type $\mathrm{Ca}^{2+}$ channels are preferential targets of neuromodulation by various neurotransmitters like GABA, glutamate, serotonin, somatostatin, and adenosine (Hille, 1994; Kavalali et al., 1997; Magee, 1999). In contrast to the other $\mathrm{Ca}^{2+}$ channel types, which provide a more constant basal $\mathrm{Ca}^{2+}$ load per action potential, the $\mathrm{Ca}^{2+}$ influx through $\mathrm{N}$-type channels is highly regulated. Consequently, the recruitment of N-type channels may determine whether the postsynaptic $\mathrm{Ca}^{2+}$ signal is below or above the threshold for LTD induction.

The G-protein-mediated modulation of the N-type channels will therefore enable or disable an activity-dependent depression in synaptic strength. This direct gain control of LTD might be relevant for learning, because learning should occur dependent on behavioral context, which could be signaled by the release of different neuromodulators.

\section{Modulation of associative LTD by backpropagating action potentials}

We have shown that $\mathrm{N}$-type $\mathrm{Ca}^{2+}$ channels are direct targets of neuromodulation via G-proteins. However, the activation of $\mathrm{N}$-type channels could be also regulated indirectly by modulation of action potential backpropagation. A $1 \mu \mathrm{M}$ concentration of $\mathrm{OH}-\mathrm{DPAT}$, which is thought to activate selectively $5-\mathrm{HT}_{1 \mathrm{~A}}$ receptors, did not affect the properties of the backpropagated spike within the first $200 \mu \mathrm{m}$ of the apical dendrite. In contrast, higher concentrations $(30 \mu \mathrm{M})$ of OH-DPAT and 5-HT induce a marked hyperpolarization of CA1 pyramidal cells by 5 and $14 \mathrm{mV}$, respectively (Andrade and Nicoll, 1987), which slightly decrease the amplitude of the backpropagated spike (Sandler and Ross, 1999). Furthermore, activation of muscarinic and adrenergic receptors regulates dendritic excitability via modulation of fast dendritic $\mathrm{Na}^{+}$ and $\mathrm{K}^{+}$channels (Johnston et al., 1999).

Both the amplitude of the backpropagated spike and the evoked dendritic $\mathrm{Ca}^{2+}$ transients decrease with distance from the pyramidal cell soma (Spruston et al., 1995; Magee and Johnston, 1997). Thus, in stratum lacunosum moleculare we would not expect any associative LTD at all, unless backpropagation of action potentials will be enhanced by activation of muscarinic or adrenergic receptors. This will lead to different learning rules for distal and proximal synapses. In general, action potential backpropagation can be very different in different types of neurons (for review, see Magee, 1999). Both CA1 and neocortical pyramidal neurons show decremental spike backpropagation (Magee and Johnston, 1997; Markram et al., 1997). Hippocampal oriens-alveus interneurons and olfactory bulb mitral cells, however, show nondecremental backpropagation of action potentials into the dendrites (Bischofberger and Jonas, 1997; Martina et al., 2000). It would be interesting to know whether glutamatergic synapses on these neurons show LTD, and if so, whether LTD has associative properties over the entire dendritic tree.

\section{Physiological significance of associative LTD}

Both associative LTD and LTP in the hippocampus may be important for the dynamical shaping of new place fields during spatial learning and theta-phase associated pyramidal cell firing (O'Keefe and Reece, 1993; Wilson and McNaughton, 1993). In particular, they may contribute to the learning of temporal sequences in the hippocampus (Skaggs and McNaughton, 1996; Mehta et al., 1997). Whereas associative LTP will strengthen the synapses that precede subsequent spike discharge of the postsynaptic cell (Magee and Johnston, 1997), associative LTD will depress EPSPs that occur too late with respect to the postsynaptic spiking, thus leading to temporally asymmetric learning rules. Such rules appeared also to be very effective for the formation of neuronal cell assemblies in artificial neural networks (Sejnowski, 1999), which was shown to be of critical importance for encoding of spatial information in the hippocampus (Wilson and McNaughton, 1993).

In conclusion, we suggest that the induction of associative LTD is a powerful mechanism to depress out-of-phase synaptic input. Thus, it may be important to have a direct gain control of associative synaptic depression, provided by the G-protein-mediated modulation of the voltage-gated N-type $\mathrm{Ca}^{2+}$ channels.

\section{REFERENCES}

Andrade R, Nicoll RA (1987) Pharmacologically distinct actions of serotonin on single pyramidal neurones of the rat hippocampus recorded in vitro. J Physiol (Lond) 394:99-124.

Bi G, Poo M (1998) Synaptic modifications in cultured hippocampal neurons: dependence on spike timing, synaptic strength, and postsynaptic cell type. J Neurosci 18:10464-10472.

Bischofberger J, Jonas P (1997) Action potential propagation into presynaptic dendrites of rat mitral cells. J Physiol (Lond) 504:359-365.

Bliss TVP, Collingridge GL (1993) A synaptic model of memory: longterm potentiation in the hippocampus. Nature 361:31-39.

Bolshakov VY, Siegelbaum SA (1994) Postsynaptic induction and presynaptic expression of hippocampal long-term depression. Science 264:1148-1152.

Cash S, Yuste R (1999) Linear summation of excitatory inputs by CA1 pyramidal neurons. Neuron 22:383-394. 
Debanne D, Gähwiler BH, Thomson SM (1994) Asynchronous pre- and postsynaptic activity induces associative long term depression in area CA1 of the rat hippocampus in vitro. Proc Natl Acad Sci USA 91:1148-1152.

Debanne D, Gähwiler BH, Thomson SM (1996) Cooperative interaction in the induction of long-term potentiation and depression of synaptic excitation between hippocampal CA3-CA1 cell-pairs in vitro. Proc Nat Acad Sci USA 93:11225-11230.

Dudek S, Bear MF (1992) Homosynaptic long term depression in area CA1 of the hippocampus and effects of NMDA receptor blockade. Proc Natl Acad Sci USA 89:4363-4367.

Dunlap K, Luebke JI, Turner TJ (1995) Exocytotic $\mathrm{Ca}^{2+}$ channels in mammalian central neurons. Trends Neurosci 18:89-98.

Fitzsimonds RM, Song H, Poo M (1997) Propagation of activity dependent synaptic depression in simple neural networks. Nature 388:439-448.

Foehring RC (1996) Serotonin modulates N- and P-type calcium currents in neocortical pyramidal neurons via a membrane-delimited pathway. J Neurophysiol 75:648-659.

Goda Y, Stevens CF (1996) Long-term depression properties in a simple system. Neuron 16:103-111.

Grynkiewicz G, Poenie M, Tsien RY (1985) A new generation of $\mathrm{Ca}^{2+}$ indicators with greatly improved fluorescence properties. J Biol Chem 260:3440-3450.

Herron CE, Lester RA, Coan EJ, Collingridge GL (1986) Frequencydependent involvement of NMDA receptors in the hippocampus: a novel synaptic mechanism. Nature 322:265-268.

Heynen AJ, Abraham WC, Bear MF (1996) Bidirectional modification of CA1 synapses in the adult hippocampus in vivo. Nature 381:163-166.

Helmchen F, Imoto K, Sakmann B (1996) $\mathrm{Ca}^{2+}$ buffering and action potential-evoked $\mathrm{Ca}^{2+}$ signaling in dendrites of pyramidal neurons. Biophys J 70:1069-1081.

Hille B (1994) Modulation of ion-channel function by G-protein-coupled receptors. Trends Neurosci 17:531-536.

Johnston D, Hoffman DA, Colbert CM, Magee JC (1999) Regulation of backpropagating action potentials in hippocampal neurons. Curr Opin Neurobiol 9:288-292.

Kavalali ET, Zhou M, Bito H, Tsien RW (1997) Dendritic $\mathrm{Ca}^{2+}$ channels characterized by recordings from isolated hippocampal dendritic segments. Neuron 18:651-663.

Kia HK, Miquel M-C, Brisorgueil MJ, Daval G, Riad M, Mestikawy SE, Hamon M, Verge D (1996) Immunocytochemical localization of serotonin $_{1 \mathrm{~A}}$ receptors in the rat central nervous system. J Comp Neurol 365:289-305.

Levy WB, Steward O (1983) Temporal contiguity requirements for longterm associative potentiation/depression in the hippocampus. Neuroscience 8:791-797.

Linden DJ (1999) The return of the spike: Postsynaptic action potentials and the induction of LTP and LTD. Neuron 22:661-666.

Magee JC (1999) Voltage gated ion channels in dendrites. In: Dendrites (Stuart G, Spruston N, Häusser M, eds), pp 139-160. Oxford UP.

Magee JC, Johnston D (1995) Synaptic activation of voltage gated channels in the dendrites of hippocampal pyramidal neurons. Science 268:301-304.

Magee JC, Johnston D (1997) A synaptically controlled, associative signal for Hebbian plasticity in hippocampal neurons. Science 275:209-213.

Majewska A, Brown E, Ross J, Yuste R (2000) Mechanisms of calcium decay kinetics in hippocampal spines: role of spine calcium pumps and calcium diffusion through the spine neck in biochemical compartmentalization. J Neurosci 20:1722-1734.

Markram H, Lübke J, Frotscher M, Sakmann B (1997) Regulation of synaptic efficacy by coincidence of postsynaptic APs and EPSPs. Science 275:213-215.

Martina M, Vida I, Jonas P (2000) Distal initiation and active propagation of action potentials in interneuron dendrites. Science 287:295-300.

Mehta MR, Barnes CA, McNaughton BL (1997) Experience-dependent, asymmetric expansion of hippocampal place fields. Proc Natl Acad Sci USA 94:8918-8921.

Mulkey RM, Malenka RC (1992) Mechanisms underlying induction of homosynaptic long-term depression in the area CA1 in the hippocampus. Neuron 9:967-975.

Neher E, Augustine GJ (1992) Calcium gradients and buffers in bovine chromaffin cells. J Physiol (Lond) 450:273-301.

Nishizuka Y (1992) Intracellular signaling by hydrolysis of phospholipids and activation of protein kinase C. Science 258:607-614.

O'Keefe J, Reece ML (1993) Phase relationship between hippocampal place units and the EEG theta rhythm. Hippocampus 3:317-330.

Oliet SH, Malenka RC, Nicoll RA (1997) Two distinct forms of long-term depression coexist in CA1 hippocampal pyramidal cells. Neuron 18:969-982.

Otani S, Connor JA (1998) Requirement of rapid $\mathrm{Ca}^{2+}$ entry and synaptic activation of metabotropic glutamate receptors for the induction of long-term depression in adult rat hippocampus. J Physiol (Lond) 511:761-770.

Sandler VM, Ross WN (1999) Serotonin modulates spike backpropagation and associated $\mathrm{Ca}^{2+}$ changes in the apical dendrites of hippocampal CA1 pyramidal neurons. J Neurophysiol 81:216-224.

Schiller J, Helmchen F, Sakmann B (1995) Spatial profile of dendritic calcium transients evoked by action potentials in rat neocortical pyramidal neurones. J Physiol (Lond) 487:583-600.

Sejnowski TJ (1999) The book of Hebb. Neuron 24:773-776.

Shigemoto R, Kinoshita A, Wada E, Nomura S, Ohishi H, Takada M, Flor PJ, Neki A, Abe T, Nakanishi S, Mizuno N (1997) Differential presynaptic localization of metabotropic glutamate receptor subtypes in the rat hippocampus. J Neurosci 17:7503-7522.

Skaggs WE, McNaughton BL (1996) Replay of neuronal firing sequences in rat hippocampus during sleep following spatial experience. Science 271:1870-1873.

Skaggs WE, McNaughton BL, Wilson MA, Barnes CA (1996) Theta phase precession in hippocampal neuronal populations and the compression of temporal sequences. Hippocampus 6:149-172.

Spruston N, Schiller Y, Stuart G, Sakmann B (1995) Activity-dependent action potential invasion and $\mathrm{Ca}^{2+}$ influx into hippocampal CA1 dendrites. Science 268:297-300.

Stanton PK, Sejnowski TJ (1989). Associative long-term depression in the hippocampus induced by Hebbian covariance. Nature 339:215-218.

Stanton PK, Chattarji S, Sejnowski TJ (1991) 2-amino-3phosphonopropionic acid, an inhibitor of glutamate-stimulated phosphoinositide turnover, blocks induction of homosynaptic long-term depression, but not potentiation, in rat hippocampus. Neurosci Lett 127:61-66.

Westenbroek RE, Hell JW, Warner C, Dubel SJ, Snutch TP, Catterall WA (1992) Biochemical properties and subcellular distribution of an N-type calcium channel $\alpha 1$ subunit. Neuron 9:1099-1115.

Wilson MA, McNaughton BL (1993) Dynamics of hippocampal ensemble code for space. Science 261:1055-1058. 